\title{
An in vitro System to Study Interactions between Bacteria and Epithelial Cells at the Molecular Level
}

\author{
By JAAP M. MIDDELDORP*† AND BERNARD WITHOLT \\ Department of Biochemistry, University of Groningen, Nijenborgh 16, 9747 AG Groningen, \\ The Netherlands
}

(Received 9 October 1981; revised 20 May 1982)

\begin{abstract}
This paper describes an experimental system to study interactions between porcine enterotoxigenic Escherichia coli (ETEC) and porcine intestinal epithelial cells in vitro at the molecular level. Radiolabelled bacteria or bacterial membrane fractions were incubated with brush borders prepared from purified epithelial cells, which were then washed repeatedly. The bacterial components removed by washing or retained by the brush borders were analysed to determine their composition and source. For this it was necessary to develop a minimal medium in which attachment factors of porcine ETEC could be radiolabelled. Furthermore, an improved method for the isolation of porcine intestinal epithelial cells was developed, since other procedures did not yield sufficiently pure preparations. The resulting method was rapid and yielded large quantities of viable epithelial cells, free from crypt cells and contaminating intestinal contents. Finally, we adapted existing procedures to isolate brush borders from these epithelial cells with special emphasis on the removal of nuclear and cytosolic material and on the isolation of morphologically intact brush borders. Using this system, mixtures of bacterial cytoplasmic and outer membranes were incubated with brush borders. Cytoplasmic membranes were easily removed by washing, while the outer membranes were not.
\end{abstract}

\section{INTRODUCTION}

Enterotoxigenic strains of Escherichia coli (ETEC) cause diarrhoea in calves, piglets and man by colonizing the small intestine and transferring enterotoxins to the epithelial cells (Richards \& Douglas, 1978). Interactions between ETEC and host cells are usually investigated microscopically. The numbers of bacteria which bind per host cell have been determined by light microscopy (Evans et al., 1978; Sellwood et al., 1975; Wilson \& Hohmann, 1974) and the morphology of the interaction has been investigated by electron microscopy (Hohmann \& Wilson, 1975; Moon et al., 1977). However, these techniques do not provide much information on the various bacterial and host components involved at the molecular level. Such information can best be obtained by studying the interactions of radioactively labelled bacteria or bacterial components with unlabelled epithelial cells or epithelial cell brush borders; bacterial components involved in adhesion should bind specifically to host cells or brush borders and should be identifiable even in the presence of large amounts of host cell material (King \& Swanson, 1978).

For these experiments, it is necessary to meet two requirements. First, ETEC have to be grown in a medium in which both incorporation of radioactive amino acids and expression of bacterial attachment factors are optimal. Since the rich media usually employed to grow ETEC (Hohmann \& Wilson, 1975; Jones \& Rutter, 1972; Nagy et al., 1976, 1977; Shipley et al., 1978; Stirm et al., 1967; Wilson \& Hohmann, 1974) are not suitable for the incorporation of

† Present address: Department of Clinical Immunology, State University Hospital, Oostersingel 59, 9713 EZ Groningen, The Netherlands. 
radioactive amino acids, a minimal medium was developed which allows labelling as well as the synthesis of attachment factor. Second, it is essential to work with purified epithelial cells and brush borders to avoid non-specific binding. Procedures for the preparation of intestinal epithelial cells and brush borders have been described for a number of animals including rat (Forstner et al., 1968; Webster \& Harrison, 1969), guinea-pig (Evans et al., 1971), man (Maestracci et al., 1975) and pig (Holmgren et al., 1975; Sellwood et al., 1975; Wilson \& Hohmann, 1974). Although adequate for morphological investigations, these procedures were not suitable for biochemical investigations due to the binding of radioactive bacterial material to non-epithelial cells or cell nuclei. We therefore modified existing methods to develop a procedure for the isolation of purified intact epithelial cells in high yields from porcine small intestine, and a procedure for the isolation of highly purified intact brush borders from these epithelial cells.

In this paper we describe the effect of growth in minimal or rich medium on the ability of bacteria to adhere to isolated epithelial cells. We also describe in detail the modified procedures for isolating epithelial cells and purifying brush borders from these cells. Such preparations are useful tools for investigating interactions between porcine ETEC and host cells at the molecular level, as illustrated by adhesion experiments involving bacterial membrane fractions and purified brush borders.

\section{METHODS}

Buffers and media. The following buffers were used: $10 \mathrm{~mm}$-sodium phosphate (pH 7.4) buffered Ringer's mammalian solution (PBR) (Altman \& Dittmer Katz, 1976); PBR supplemented with $1 \mathrm{mg}$ glucose $\mathrm{ml}^{-1}$ and $5 \mu \mathrm{g}$ trypsin inhibitor $\mathrm{ml}^{-1}$ (Sigma) (IPBR); Eagles minimal essential medium (Altman \& Dittmer Katz, 1976) supplemented with $9 \mathrm{mM}-\mathrm{CaCl}_{2}, 100000 \mathrm{U}$ penicillin $\mathrm{l}^{-1}, 0.5 \mathrm{~g}$ streptomycin $\mathrm{l}^{-1}$ and $2.5 \mathrm{mg}$ fungizon $\mathrm{1}^{-1}$ (Eagles MEM); 0.2 M-sorbitol, $12.5 \mathrm{mM}-\mathrm{NaCl}, 10 \mathrm{~mm}$-sodium phosphate buffer (pH 7.4) (final buffer); final buffer supplemented with $0.5 \mathrm{mM}$-EDTA (isolation buffer); final buffer with $10 \mathrm{mM}-\mathrm{MgCl}_{2}\left(\mathrm{Mg}^{2+}\right.$-buffer).

Bacteria and growth conditions. The $E$. coli strains used are shown in Table 1 . Most were originally isolated from pigs with diarrhoeal disease (Guinée $e t$ al., 1977); they were the kind gift of Dr P. A. M. Guinée (Rijks Instituut voor de Volksgezondheid, Bilthoven, The Netherlands). To maximize expression of adhesion factors in rich media, strains were grown for 1 or 2 weeks at $37^{\circ} \mathrm{C}$ in stationary tubes containing $10 \mathrm{ml}$ of one of the following média (P. A. M. Guinée, personal communication): $0.8 \%(\mathrm{w} / \mathrm{v})$ Nutrient Broth (Difco), Nutrient Broth supplemented with $10 \%(\mathrm{v} / \mathrm{v})$ horse serum or $3.7 \%(\mathrm{w} / \mathrm{v})$ Brain Heart Infusion (Difco). Bacteria were also grown to the stationary phase $(16 \mathrm{~h})$ on a rotary shaker at 200 r.p.m., which gave a density of about $1.2 \mathrm{mg}$ dry weight $\mathrm{ml}^{-1}$ (Witholt et al., 1976) in a minimal medium containing E-salts (Vogel \& Bonner, 1956), $0 \cdot 5 \%$ (w/v) dextrose and $1 \%$ (w/v) Basal Medium Eagle vitamins (Flow Laboratories).

Isolation of attachment factor $K 88_{a b}$. Escherichia coli strain 2100 cells were harvested from 8.41 minimal medium and suspended in $150 \mathrm{ml} \mathrm{0.1} \mathrm{M}$-phosphate buffer ( $\mathrm{pH} \mathrm{7.5).} \mathrm{Attachment} \mathrm{factor} \mathrm{was} \mathrm{sheared} \mathrm{off} \mathrm{the} \mathrm{cells} \mathrm{in} \mathrm{a} \mathrm{Waring}$ blender ( $1 \mathrm{~min}$ at half maximum power) and isolated by acid precipitation according to Stirm et al. (1967). The final $\mathrm{K} 88_{\mathrm{ab}}$ pellet was dissolved in water, dialysed against water at $0-4{ }^{\circ} \mathrm{C}$ for 1 week, lyophilized to a white powder, and stored at $-20^{\circ} \mathrm{C}$.

Samples of purified $\mathrm{K} 88_{\mathrm{ab}}, \mathrm{K} 88_{\mathrm{ac}}, \mathrm{K} 88_{\mathrm{ad}}$ and $\mathrm{K} 88_{\mathrm{ad}(\mathrm{e})}$ were kindly provided by Dr F. Mooi and Dr Gaastra (University of Amsterdam, The Netherlands). Antiserum against $\mathrm{K}_{\mathrm{ab}}$ was kindly provided by Dr P. A. M. Guinée.

Radioactive labelling and isolation of bacterial membrane fractions. Strain 2100 was labelled continuously with ${ }^{35} \mathrm{~S}$ ]methionine $\left(28.49 \mathrm{TBq}\right.$ mmol ${ }^{-1}$, Amersham) in minimal medium at $37^{\circ} \mathrm{C}$ or at $18^{\circ} \mathrm{C}$. Harvested cells were converted to sphaeroplasts (Witholt $e t$ al., 1976) and lysed by sonication ( 7 periods of $15 \mathrm{~s}$ at $50 \mathrm{~W} \mathrm{0-4}{ }^{\circ} \mathrm{C}$, Branson Sonifier B12, Branson Sonic Power Co., Danbury, Conn., U.S.A.) in the presence of DNAase and RNAase (De Leij \& Witholt, 1977). Large fragments were removed from the lysate by centrifugation at $5000 \mathrm{~g}$ for $10 \mathrm{~min}$ and total membranes (TM) were obtained from the supernatant fraction by centrifugation at $190000 \mathrm{~g}$ for $2 \mathrm{~h}$. Outer membranes and large cell fragments were removed from the lysate by centrifugation at $30000 \mathrm{~g}$ for $15 \mathrm{~min}$ and a crude cytoplasmic membrane (CM) fraction was obtained by centrifuging the supernatant at $190000 \mathrm{~g}$ for $2 \mathrm{~h}$. This CM fraction contained approximately $20 \%$ outer membrane material which was not sedimented by the first centrifugation step.

Isolation of intact epithelial cells from porcine small intestine. Intestines were removed from one year old slaughter pigs starved for 12-18 h prior to slaughter. Immediately after death the intestines were dissected out and a $1.5 \mathrm{~m}$ length from the middle of each small intestine was placed on ice. The luminal contents of these segments were 
Table 1. E. coli strains used in this study

\begin{tabular}{ll}
\multicolumn{1}{c}{ Strain } & \multicolumn{1}{c}{ Serotype } \\
$1900(\mathrm{~B} 41)^{*}$ & O101:K $: \mathrm{K} 99$ \\
2000 & O149:K91:K88 ${ }_{\mathrm{ab}}$ \\
$2100(\mathrm{G} 7)^{*}$ & O8 $: \mathrm{K} 87: \mathrm{K} 88_{\mathrm{ab}}$ \\
$2200 \dagger$ & $\mathrm{C} 600\left(\mathrm{~K} 88_{\mathrm{ab}}\right)$ \\
2800 & O8:K442 \\
$2900 \ddagger$ & O9:K103 \\
$3000 \ddagger$ & O9:K 103
\end{tabular}

* Designations used by Orskov et al. (1977).

$\dagger \mathrm{K} 88_{\mathrm{ab}}$ plasmid from strain 2100 (G7) introduced into E. coli C600 by P. A. M. Guinée.

$\ddagger$ A single strain was stored on solid media to select for maximal (2900) and minimal (3000) P-987 production (Nagy et al., 1977).

minimal so that a two-step wash was sufficient to remove non-mucous material. Segments of approximately $20 \mathrm{~cm}$ were cut immediately after removal of the intestine and flushed with ice-cold PBR, directly followed by gentle flushing with $30 \mathrm{ml}$ ice-cold IPBR per segment. The segments were transported in IPBR on ice and everted. The everted segments were dipped in fresh IPBR, and transferred to $200 \mathrm{ml}$ IPBR at room temperature. Epithelial cells were separated from the underlying tissue by shaking at 100 r.p.m. for 5-10 min. After removal of the gut segments, the epithelial cells were harvested by centrifugation at $200 \mathrm{~g}$ for $10 \mathrm{~min}$ at $0{ }^{\circ} \mathrm{C}$, gently resuspended, washed carefully in PBR $\left(0^{\circ} \mathrm{C}\right)$, and centrifuged again. The washed cells were gently suspended in cold Eagles MEM to a density of about $10^{6}-10^{7}$ cells ml ${ }^{-1}$. When needed immediately, the cells were stored at $0-4{ }^{\circ} \mathrm{C}$ in a $300-$ $400 \mathrm{ml}$ beaker; a large surface-to-volume ratio appeared necessary to maximize oxygen diffusion. Such cells were still $70 \%$ viable after storage for $4 \mathrm{~h}$. Prolonged storage at $0-4{ }^{\circ} \mathrm{C}$ rendered the cells more sensitive to agitation, so for most adhesion experiments the cells were used within $1 \mathrm{~h}$ of isolation. For long-term storage, glycerol was added to the cell suspension to a final concentration of $15 \%(\mathrm{v} / \mathrm{v})$ and small volumes, frozen in liquid nitrogen, were stored at $-80^{\circ} \mathrm{C}$. The viability of such stored cells, which was high directly after thawing, decreased rapidly. Storage at $-80^{\circ} \mathrm{C}$ was most useful when large numbers of cells were needed for the isolation of brush borders.

Isolation of brush borders. The isolation of brush borders from rat (Forstner et al., 1968), pig (Forsyth et al., 1978; Sellwood et al., 1975) and other animals (Mooseker, 1976) has been described. Some of these procedures (Forstner et al., 1968; Sellwood et al., 1975) were unsatisfactory, since they yielded fragmented brush borders or failed to separate brush borders from the underlying cellular material (Mooseker, 1976) or from cell nuclei (Forstner et al., 1968; Forsyth et al., 1978). An improved procedure (Fig. 1) using SDS-PAGE to follow the removal of non-brush border proteins and phase-contrast microscopy to follow the morphology of the brush borders at various stages of purification was developed. Epithelial cell suspensions $\left(10^{9} \mathrm{cells}^{-1}\right)$ were washed twice in PBR $\left(0^{\circ} \mathrm{C}\right)$ and centrifuged at $200 \mathrm{~g}$ for $10 \mathrm{~min}$ (Fig. 1 a). The pellet was suspended in $5 \mathrm{~mm}-\mathrm{NaHCO}_{3}(\mathrm{pH} 8 \cdot 2$ ) by repeated passage through a syringe with a $0.7 \mathrm{~mm}$ bore needle. The cells were gently homogenized by about 40 up and down strokes in a Dounce tissue grinder with a loosely fitting pestle (clearance $0.005 \mathrm{~cm}$ ) until all epithelial cells were disrupted and little cytoplasmic material was left on the brush border basal side as seen by phase-contrast microscopy (Fig. 1b). To remove terminal web filamentous material from brush borders, the cell homogenate was centrifuged at $450 \mathrm{~g}$ for $10 \mathrm{~min}$, and the pellet resuspended in isolation buffer (Dounce, 10 strokes) and centrifuged again. The brush borders were separated from underlying material by one to two washes in isolation buffer. Homogenization in hypotonic medium and low speed centrifugation easily removed most cell fragments (Fig. 1c) except nuclei (Fig. 1 d). To remove these, the final pellet was resuspended in $\mathrm{Mg}^{2+}$-buffer using a Dounce tissue grinder and stored at $0-4{ }^{\circ} \mathrm{C}$ in a glass column (Fig. 1e) for 30-60 min until a substantial sediment had developed (modified from Kessler et al., 1978). The supernatant fraction was carefully removed and filtered through glass wool $(1 \mathrm{~g}$ to $10 \mathrm{ml}$ suspension) as indicated in Fig. $1(f)$ (from Forstner $e t$ al., 1968). The resulting filtrate was centrifuged at $450 \mathrm{~g}$ for $10 \mathrm{~min}$ and the brush border pellet was suspended in final buffer (Fig. $1 \mathrm{~g}$ ). Purity was assessed by SDS-PAGE (Fig. 3, lane 9), phase-contrast microscopy and sucrose-density gradient centrifugation analysis (a typical pattern is shown in Fig. $1 h$ ).

For long-term storage, brush border suspensions in final buffer were frozen in liquid nitrogen and kept at $-80^{\circ} \mathrm{C}$. The brush borders in such suspensions remained intact and showed unchanged protein profiles for several months. Before use in adhesion tests the brush borders were washed and suspended in PBR.

Adhesion between bacteria and epithelial cells or between bacterial membrane fragments and brush borders. Adhesion experiments with intact epithelial cells were performed by a modification of the method of Svanborg-Eden $e t$ al. (1977). Epithelial cells from fresh isolates were generally used. Bacteria were suspended in PBR after harvesting at $5000 \mathrm{~g}$ for $10 \mathrm{~min}$. Bacteria $\left(10^{8}\right.$ in $\left.200 \mu \mathrm{l}\right)$ were added to epithelial cells $\left(10^{5}\right.$ in $\left.200 \mu \mathrm{l}\right)$ and the mixture was incubated for $45 \mathrm{~min}$ at $37^{\circ} \mathrm{C}$. PBR was used for both incubation and washes. There was increased adhesion to 

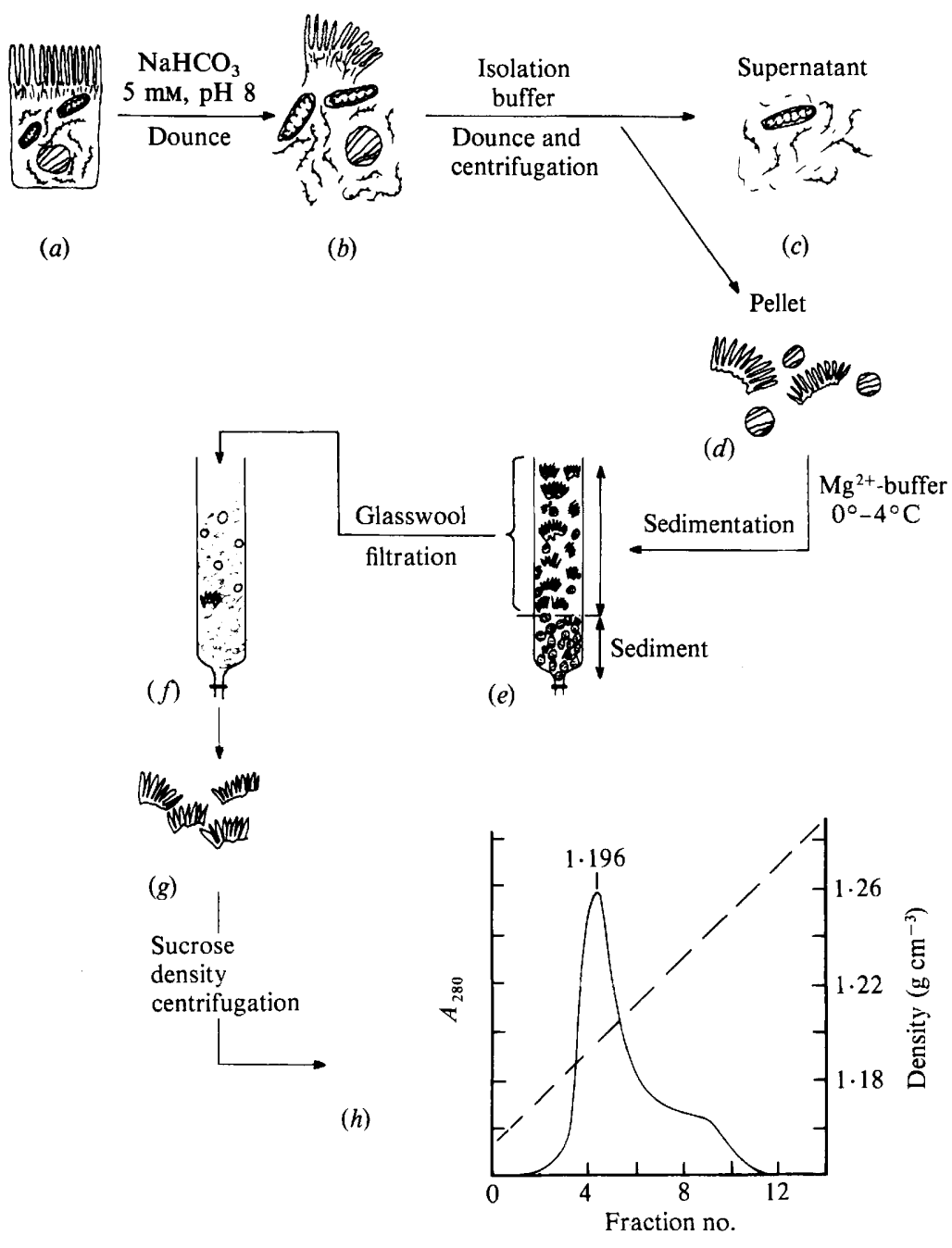

Fig. 1. Schematic representation of isolation steps and morphology during purification of brush borders. For details see Methods. ( $h$ ) Density (---), absorbance (-).

areas where the epithelial cell membranes had been damaged ('puffs'). Therefore, only intact epithelial cells were counted in the adhesion experiments. Brush borders were incubated with radiolabelled bacterial membranes by adding $200 \mu \mathrm{l}$ brush border suspension to $100 \mu \mathrm{l}$ labelled membranes and shaking them in polycarbonate tubes for $45 \mathrm{~min}$ at $37^{\circ} \mathrm{C}\left(100\right.$ cycles $\left.\mathrm{min}^{-1}\right)$. The incubation was stopped by adding $1 \mathrm{ml}$ ice-cold PBR. Brush borders were sedimented by centrifugation at $800 \mathrm{~g}$ for 3-5 min. The supernatant fraction was stored and the brush borders were washed with $1 \mathrm{ml}$ PBR $\left(0^{\circ} \mathrm{C}\right)$ followed by centrifugation as above. This treatment was repeated five times. Supernatant fractions (washes) and the final washed brush border pellet were analysed by scintillation counting and sucrose-density gradient centrifugation.

Analytical procedures. Phase-contrast microscopy was used to follow the appearance of epithelial cells during their isolation, and cells were counted in a Bürker-Türk counting chamber. Phase-contrast microscopy was also used to distinguish epithelial cells, with their characteristic columnar shape and brush border region (Evans et al., 1971), from other intestinal cell types. Viability was tested by trypan blue exclusion. The removal of epithelial cells from the intestinal villi was followed by microscopy. Gut samples taken during isolation were fixed in $2.5 \%(\mathrm{v} / \mathrm{v})$ glutaraldehyde and prepared for thin-section microscopy. Fixed gut samples were dehydrated, embedded in paraffin and thin sections were stained with the periodic acid-Schiff reagent to show the mucus layer.

Sucrose-density gradient analysis was performed according to De Leij et al. (1977), and radioactivity was counted as described by De Leij et al. (1979). SDS-PAGE was done according to Laemmli (1970) using $12.5 \%$ 
(w/v) acrylamide gels. Gels were stained with Fast Green. Protein was determined by the Lowry method using bovine serum albumin as standard.

Slide agglutination tests were performed by adding one drop of bacterial suspension to one drop of antiserum at $1: 20$ dilution on a microscope slide and agglutination was observed after $1 \mathrm{~min}$. Ouchterlony double diffusion was performed as described by lsaacson (1977).

\section{RESULTS}

\section{Isolation of porcine intestinal epithelial cells and the corresponding brush borders}

Early observations indicated that epithelial cells were very easily detached from the villi. Incubation times longer than 15 min decreased the viability of the epithelial cells and caused the release of other cell types, resulting in cell preparations which contained mostly crypt and lamina propria cells. The viability of epithelial cells was increased markedly by buffering to pH 7.4 (Evans et al., 1971) and by addition of glucose and trypsin inhibitor during isolation. EDTA, as used by Evans et al. (1971), destabilized the cell membranes and was therefore not used. Despite these precautions and the speed with which the first flushing steps were carried out, epithelial cells were already detached from the lamina propria when the intestinal segments were everted, as can be seen in Fig. $2(a, b)$. Gentle shaking of these everted segments released the epithelial cells into the medium in large sheets (Fig. $2 c$ ) which formed small clumps of cells on subsequent washing or on agitation of the suspension. Individual cells were more easily damaged than cells still attached to one another. It was important therefore to avoid unnecessary agitation during the isolation of epithelial cells.

Suspensions prepared as described above (see Methods), contained more than $95 \%$ epithelial cells, with a viability of $80-90 \%$ in fresh isolates. The entire isolation could be completed within $30-40 \mathrm{~min}$ of killing the pig, which minimized damage to the epithelial cells due to autolysis. These suspensions were used either to test the effect of different growth media on the adhesion of various ETEC strains to epithelial cells, or to prepare brush borders.

To purify brush borders and to separate them from nuclei we combined a series of purification steps as illustrated diagrammatically in Fig. 1. The resulting procedure yielded open brush borders which, when compared to nuclei, accounted for $95-99 \%$ of the cell fragments seen by phase-contrast microscopy. The enrichment of two typical brush border constituents (actin and myosin with mol. wt of 42000 and 200000 , respectively; Mooseker, 1976) and the corresponding decrease of nuclear protein (histones with mol. wt of 10000, 12500,13000 and 14000; Altman \& Dittmer Katz, 1976) during the brush border isolation is shown in Fig. 3. Based on the relative histone content of brush borders before (Fig. 3, lane 7) and after purification (lane 9) the final brush border suspension contained, at most, $5 \%$ nuclear material, as routinely found for more than 25 separate isolations. The brush borders isolated by this procedure remained intact, with very little contamination on the cytosolic side, as seen by phase-contrast microscopy. They banded at a density of $1 \cdot 185-1.210 \mathrm{~g} \mathrm{~cm}^{-3}$ on sucrose gradients, corresponding to $39 \cdot 3-44 \%$ $(w / w)$ sucrose at $20^{\circ} \mathrm{C}$ (Fig. $1 h$ ).

\section{Development of a medium suitable for radiolabelling and expression of functional attachment factors}

In a previous paper we described a minimal medium suitable for labelling of ETEC with radioactive amino acids (Middeldorp \& Witholt, 1981). The utility of this medium for our studies depended on the synthesis of functional attachment factors. Slide agglutination tests with anti-K88 antiserum showed that $K 88_{a b}$ strains produced $K 88_{a b}$ antigen in minimal as well as in rich media.

To establish the identity of the K88 antigen produced by strain 2100 in minimal medium, it was isolated to near homogeneity ( $90-95 \%$ ) and compared to K88 variants isolated by Mooi \& De Graaf (1979). SDS-PAGE and immunodiffusion against anti-K $88_{\mathrm{ab}}$ antiserum identified the $\mathrm{K} 88$ variant produced by strain 2100 as $\mathrm{K} 88_{\mathrm{ab}}$ (data not shown). To determine whether the $\mathrm{K} 88_{\mathrm{ab}}$ antigen synthesized in minimal medium was expressed as a functional attachment factor, we measured the adhesion of whole bacteria to isolated epithelial cells. Strains possessing $\mathrm{K} 88_{\mathrm{ab}}$ 

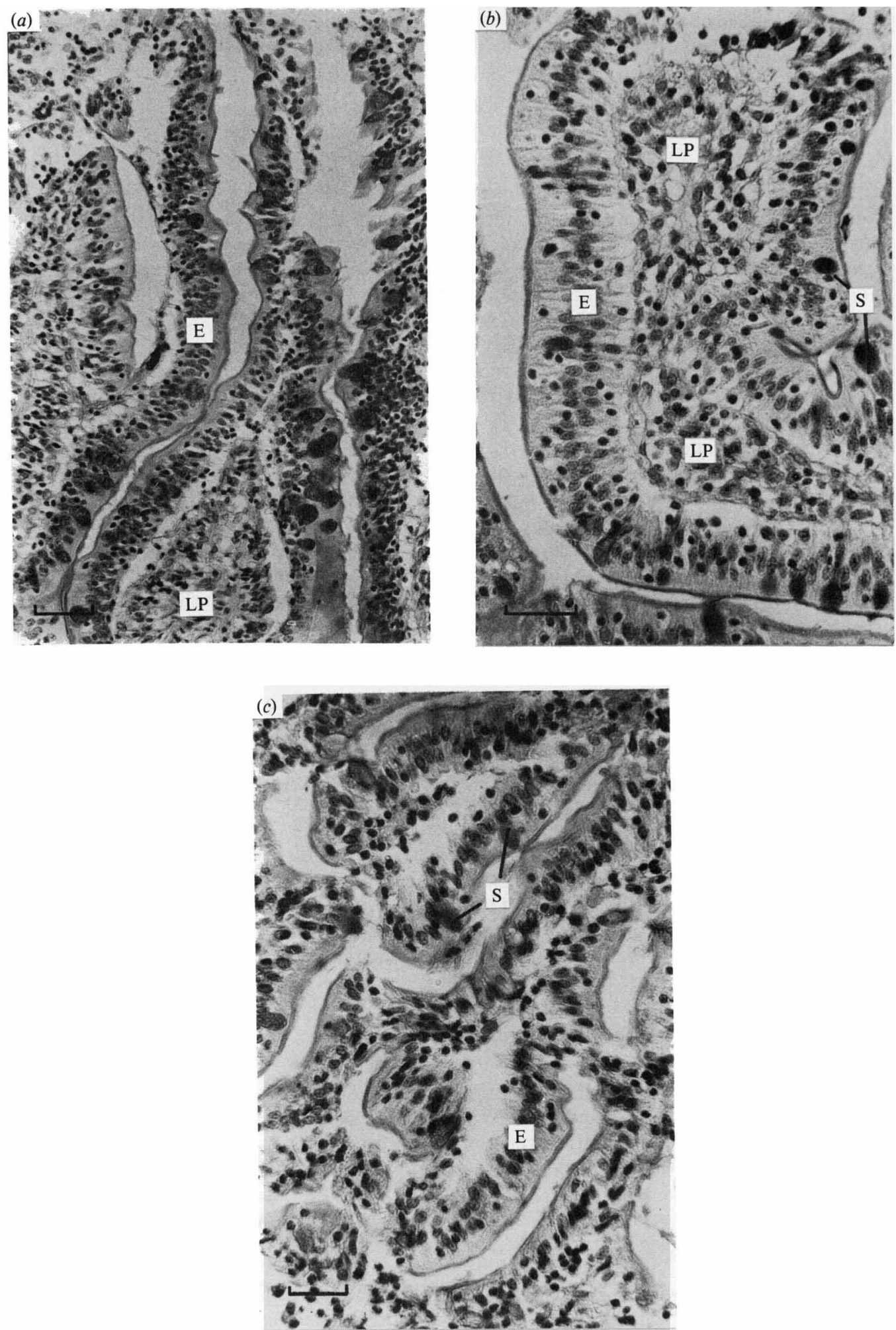


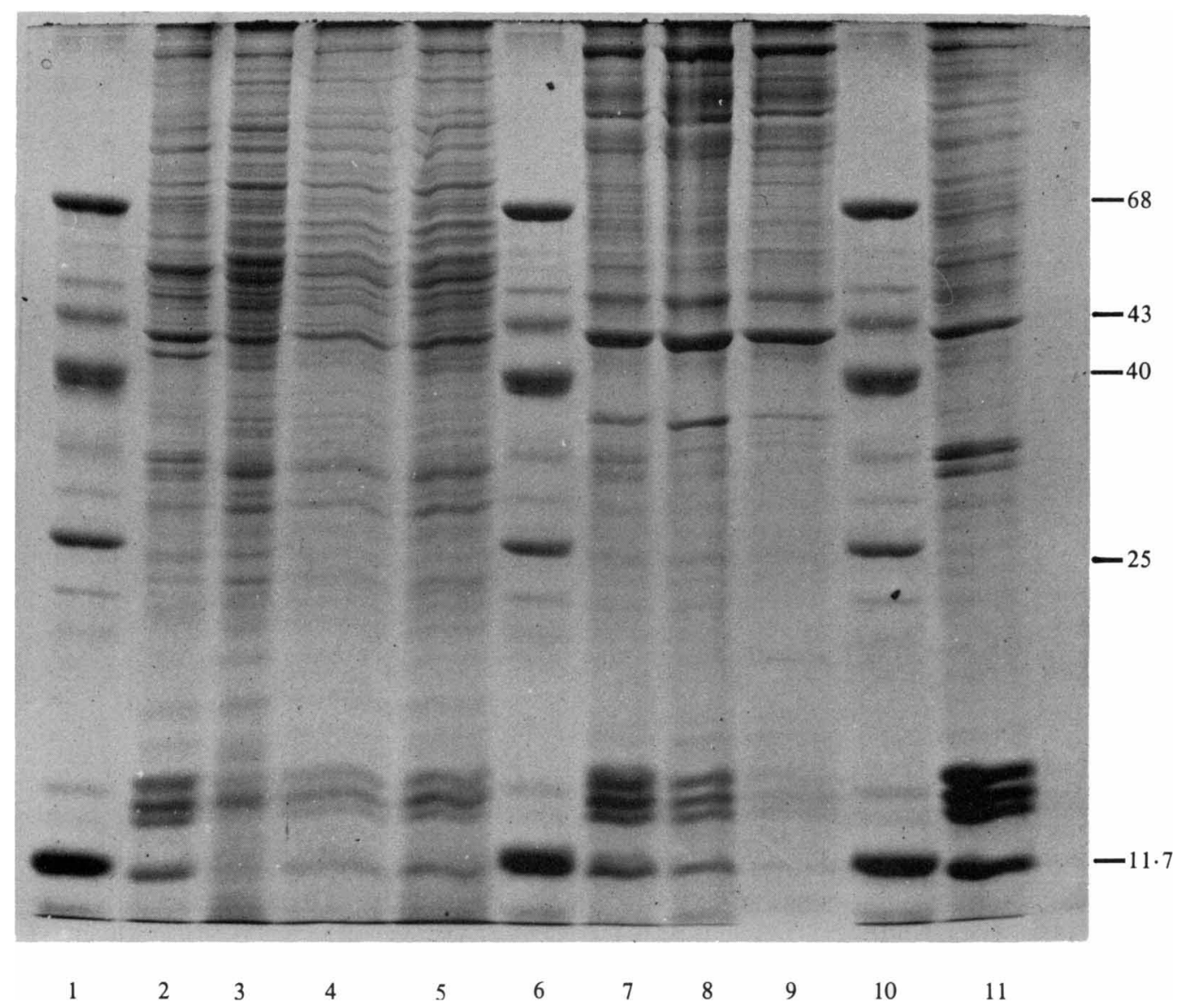

Fig. 3. SDS-PAGE of samples taken during the isolation of brush borders from porcine small intestinal epithelial cells. Lanes 1, 6 and 10: reference proteins (from top to bottom: bovine serum albumin, hen ovalbumin, aldolase, chymotrypsinogen, and cytochrome $c$ with molecular weights of $68000,43000,40000,25000$ and 11700 , respectively). Lane 2: whole epithelial cells. Lanes 3, 4 and 5: supernatant fractions from hypotonic homogenization (3) and washing $(4,5)$ steps. Lane 7 : material before the $\mathbf{M g}^{2+}$-sedimentation step. Lane 8: supernatant fractions of the $\mathbf{M g}^{2+}$-sedimentation step. Lane 9: purified brush borders after glasswool filtration. Lane $11:$ material remaining in the glasswool after filtration and recovered by squeezing.

antigen showed pronounced adhesion in minimal medium (Fig. 4, upper two strains). Although the $\mathrm{K} 88_{\mathrm{ab}}$-mediated adhesion occurred over the whole epithelial cell, the bacterial density was by far the greatest on the brush border side of the cell, indicating that the K88-receptor is concentrated at the brush border region, which is the only point of contact in vivo. This was especially the case for strain 2100 , which showed a complete coverage of the brush border area. Strain 2100 was also cultured at $18^{\circ} \mathrm{C}$, which prevents $\mathrm{K} 88$ formation (Jones \& Rutter, 1972; Middeldorp \& Witholt, 1981). After one growth cycle at $18^{\circ} \mathrm{C}$ some adhesion to epithelial cells

Fig. 2. Thin sections of fixed gut segments, taken after transportation and eversion as described in the text. Segments were stained with the periodic acid-Schiff reagent to show the presence of the mucus layer (dark lining) and individual slime cells (S). The time elapsed after killing the pig was about $15 \mathrm{~min}$. At this point epithelial cells (E) had already become detached from the lamina propria (LP) $[(a)$ and at higher magnification $(b)$ ]. The epithelial cells became detached as large sheets of cells $(a)$ and were found as such in the medium $(c)$. The bar markers in $(a)$ and $(c)$ represent $30 \mu \mathrm{m}$ and the bar marker in (b) represents $10 \mu \mathrm{m}$. 


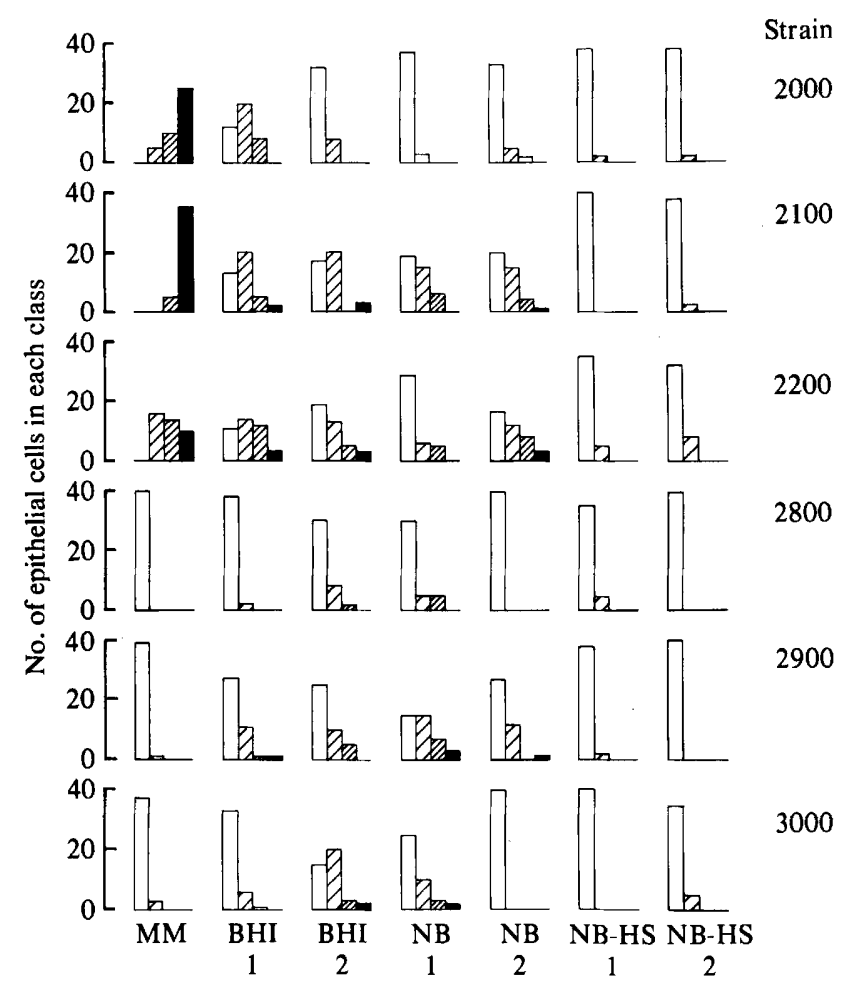

Fig. 4. Binding of various $E$. coli strains to isolated porcine intestinal epithelial cells. Six strains of $E$. coli were grown in minimal medium or in one of three rich media for one (1) or two (2) weeks and added to epithelial cells as described in Methods. MM, minimal medium; BHI, Brain Heart Infusion; NB, Nutrient Broth; NB-HS, Nutrient Broth supplemented with horse serum. The bars of each histogram show four classes of epithelial cells: $\square, 0-9$ bacteria; $\square, 10-19$ bacteria; $\mathbb{Z}, 20-29$ bacteria; $\square,>30$ bacteria. The number of bacteria indicates the number of organisms attached per epithelial cell.

was still evident but repeated cultivation at $18^{\circ} \mathrm{C}$ completely abolished adhesion and cell agglutination with anti-K88 $8_{\mathrm{ab}}$ serum. A K12 strain harbouring a K88-coding plasmid (strain 2200 ) also produced functional K88 pili; total adhesion was slightly less than for strain 2100 (Fig. 4). Other piliated strains, such as $08: \mathrm{K}^{\prime \prime} 442^{\prime \prime}: \mathrm{P}^{+}$(this strain was derived from strain 2800) and a $\mathrm{K}^{+} 9^{+}$strain [0101: $\mathrm{K}^{-}: \mathrm{K} 99$ (B41)] also showed adhesion in this system although the total number of bound bacteria was less than that with K88 strains (data not shown).

Finally, differences among adhering and non-adhering strains were clear when they were grown in minimal medium but were reduced considerably or eliminated when these same strains were grown in rich media (Fig. 4). During repeated experiments using identical conditions for bacterial growth we always found similar results with each type of K88-receptor in different isolates as has been reported by Sellwood et al. (1975).

\section{Interaction of labelled bacterial fragments and isolated brush borders}

Escherichia coli strain 2100 was labelled with $\left[{ }^{35} \mathrm{~S}\right]$-methionine in minimal medium, and the various isolated membrane fractions were added to purified brush borders. After incubation for $45 \mathrm{~min}$ at $37^{\circ} \mathrm{C}$, the brush borders were washed five times to remove non-binding material. The results for two such experiments are shown in Table 2 and Fig. 5. The total membrane fraction (TM) consisted of unseparated outer and inner membranes as shown by sucrose density gradient analysis (Fig. 5). The first wash removed nearly three-quarters of the radioactivity originally added to the brush borders; this wash preferentially removed cytoplasmic membrane material (Fig. 5), implying that the brush borders preferentially bound the outer membrane material present in the total membrane preparation. The same was true for a partially purified cytoplasmic membrane preparation (Table 2) in which case it was contaminating outer 


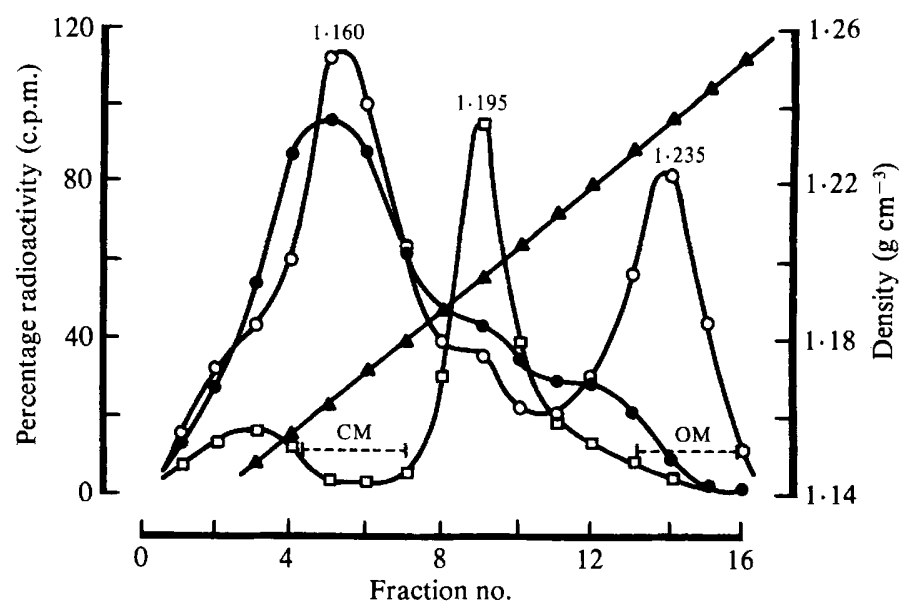

Fig. 5. Sucrose-density gradient centrifugation of radiolabelled $E$. coli total membranes before and after interaction with brush borders. $O$, Total membranes before adhesion;, , membranes removed in the first wash; $\square$, material which remained bound to the brush borders after five washes; $\boldsymbol{\Delta}$, density. Gradient profiles were normalized to fit within the same figure. The $100 \%$ value for $O, O$ and $\square$ represents $10^{5}$ c.p.m., $10^{4}$ c.p.m. and $10^{3}$ c.p.m., respectively. Repeated experiments always gave similar results, however, before each experiment the membrane composition of the total membrane was always analysed separately on sucrose-gradients in order to check for complete (OM- and CM-) membrane separation. OM, outer membrane; CM, cytoplasmic membrane.

\section{Table 2. Binding of radiolabelled bacterial fragments to isolated brush borders}

Brush border protein $(1 \mathrm{mg})$ was incubated with $117 \mu \mathrm{g}$ total membrane $(\mathrm{TM})$ protein $\left(2.82 \times 10^{7}\right.$ c.p.m. $=100 \%$ ). Brush border protein $(3.3 \mathrm{mg})$ was incubated with $13 \mu \mathrm{g}$ cytoplasmic membrane $(\mathrm{CM})$ protein $\left(3.1 \times 10^{6}\right.$ c.p.m. $\left.=100 \%\right)$.

\begin{tabular}{|c|c|c|c|c|c|c|c|}
\hline \multirow[b]{3}{*}{$\begin{array}{l}\text { Bacterial } \\
\text { fraction }\end{array}$} & \multicolumn{6}{|c|}{ Percentage radioactivity recovered in: } & \multirow[b]{3}{*}{$\begin{array}{c}\text { Total recovery } \\
(\%)\end{array}$} \\
\hline & \multicolumn{5}{|c|}{ Washes } & \multirow[b]{2}{*}{$\begin{array}{c}\text { Washed brush } \\
\text { borders }\end{array}$} & \\
\hline & 1 & 2 & 3 & 4 & 5 & & \\
\hline TM & $71 \cdot 6$ & $4 \cdot 5$ & $1 \cdot 6$ & - & - & $18 \cdot 2$ & $95 \cdot 9$ \\
\hline $\mathrm{CM}$ & $76 \cdot 0$ & 6.4 & 1.7 & $1 \cdot 5$ & 0.9 & $12 \cdot 2$ & 98.7 \\
\hline
\end{tabular}

membrane material which remained bound to the brush borders (data not shown). This outer membrane material was bound tightly to the brush borders since it was not removed by the third, fourth and fifth washes (Table 2) and on sucrose-density gradient analysis it ran at the same density as purified brush borders (compare Fig. 5 and Fig. $1 h$ ). The same was true for the partially purified cytoplasmic membrane preparation (data not shown). Analysis of the various fractions by SDS-PAGE and fluorography established that the material which remained bound to the brush borders consisted of outer membrane fragments enriched with respect to $\mathrm{K} 88_{\mathrm{ab}}$, as has recently been described elsewhere (Middeldorp \& Witholt, 1981). The results shown in Table 2 and Fig. 5 are typical of this type of experiment and show that molecular details can be studied even in the presence of large amounts of non-binding material.

\section{DISCUSSION}

In this paper we describe improved methods for the preparation of purified epithelial cell brush borders and of radioactively labelled bacterial components recently used to study the interactions of bacteria and epithelial cells in vitro and at the molecular level (Middeldorp \& Witholt, 1981). 
Epithelial cells were easily lost in the initial washing steps when preparation procedures described by other workers were employed. By using a few gentle washes in the presence of trypsin inhibitor to block intestinal proteases, satisfactory epithelial cell suspensions were obtained. These suspensions could then be used to prepare nearly homogeneous brush border preparations as determined by phase-contrast microscopy and SDS-PAGE.

By growing bacteria in a minimal medium, which allowed radiolabelling of membrane proteins, full expression of $\mathrm{K}^{88_{-}}$ab pili and probably other attachment factors as well was achieved. Although a minimal medium is unlikely to mimic the in vivo intestinal environment, the same might be said of rich media such as nutrient broth or brain heart infusion. Synthesis of $\mathrm{K} 99$ pili is blocked in the presence of $\mathrm{L}$-alanine, explaining why rich media, which contain $\mathrm{L}$ alanine, inhibit the synthesis of K99 (De Graaf et al., 1980). Synthesis of K88 also seems to be blocked in rich media (Fig. 4). Other components of rich media which block the synthesis of K88 may include trace metals, since no synthesis of functional K88 occurred when trace metals were added to the minimal medium.

Gram-negative bacteria such as $E$. coli are endowed with a cytoplasmic and an outer membrane. It might be expected that attachment factors such as pili, which presumably originate in the outer membrane, attach to receptors on host cells and thus link whole cells or outer membrane fragments to such cells. When mixtures of outer and cytoplasmic membranes interact with brush borders (Table 2 and Fig. 5) it is the cytoplasmic membrane fraction which is removed by washing, presumably leaving outer membrane fragments behind. More detailed experiments which utilize the adhesion system described in this paper showed that outer membranes do indeed bind to brush borders (Middeldorp \& Witholt, 1981). This binding depended on the presence of $\mathrm{K} 88_{\mathrm{ab}}$ attachment factor, and was independent of how the outer membranes were prepared (Middeldorp \& Witholt, 1981). Thus, outer membrane fragments which are released into the medium (Gankema et al., 1980; Hoekstra et al., 1976; MugOpstelten \& Witholt, 1978; Wensink \& Witholt, 1981), periplasmic outer membrane fragments (Gankema et al., 1980; Wensink et al., 1978) and cellular outer membrane (De Leij \& Witholt, 1977) all bound to purified brush borders, while the corresponding cytoplasmic membranes, or outer membranes of non-piliated cells, did not. Since the release of outer membrane fragments by growing cells is a normal phenomenon (Gankema et al., 1980; Hoekstra et al., 1976; MugOpstelten \& Witholt, 1978; Wensink \& Witholt, 1981), and since the heat-labile enterotoxin (LT) of E. coli is associated with the outer membrane (Gankema et al., 1980; Wensink et al., 1978), the interaction of released outer membrane fragments and host epithelial cells may be physiologically significant. Specifically, released outer membrane fragments may function as toxin carriers as we have suggested in a recent model (Middeldorp \& Witholt, 1981).

The experimental system described above provides the basic tools to study such interactions in detail, and should be useful in elucidating the molecular events which occur when bacterial and eukaryotic membranes happen to encounter one another under conditions of symbiosis or pathogenesis.

We wish to thank Dr P. A. M. Guinée for providing strains and antisera, Drs F. Mooi, W. Gaastra, and F. de Graaf for providing purified K88 variants, Ms L. de Vries and Dr P. Nieuwenhuis for thin-sectioning and microscopy, Mr N. Panman for drafting the figures, Mr K. Gillesen for photography and Ms K. Tinga and Ms I. Sybesma for typing the manuscript.

\section{REFERENCES}

Altman, P. L. \& Dittmer Katz, D. (editors) (1976). Cell Biology I, pp. 65-67 and p. 386. Bethesda: Federal American Society for Experimental Biology. De Graaf, F. K., Klaasen-Boor, P. \& Van Hees, J. E. (1980). Biosynthesis of the K99 surface antigen is repressed by alanine. Infection and Immunity 30, 125-128.
DE LEIJ, L. \& WitholT, B. (1977). Structural heterogeneity of the cytoplasmic and outer membranes of Escherichia coli. Biochimica et biophysica acta 417, 92104.

De LeiJ, L., Kingma, J. \& Wirholt, B. (1979). Nature of the regions involved in the insertion of newly synthesized protein into the outer membrane of 
Escherichia coli. Biochimica et biophysica acta 553, 224-234.

Evans, D. G., Evans, D. J., Tuoa, W. S. \& Dupont, H. L. (1978). Detection and characterization of colonization factor of enterotoxigenic Escherichia coli isolated from adults with diarrhoea. Infection Immunity 19, 727-736.

Evans, E. M., Wrigglesworth, J. M., Burdett, K. \& POVER, W. F. R. (1971). Studies on epithelial cells isolated from guinea pig small intestine. Journal of Cellular Biology 51, 452-464.

ForstNer, G. G., SABESIN, S. M. \& ISSElbaChER, K. J. (1968). Rat intestinal microvillus membrane: purification and biochemical characterization. Biochemical Journal 106, 381-390.

Forsyth, G. W., Hamilton, D. L., Goertz, K. E. \& OLIPHANT, L. W. (1978). Some comparative properties and localization of porcine jejunal adenylate cyclase. Canadian Journal of Biochemistry 56, 280 286.

Gankema, H., Wensink, J., Guinée, P. A. M., JANSEN, W. H. \& WitholT, B. (1980). Some characteristics of the outer membrane material released by growing enterotoxigenic Escherichia coli. Infection and Immunity 29, 704-713.

Guinée, P. A. M., Agterberg, C. M., Jansen, W. H. \& FRIK, J. F. (1977). Serological identification of pig enterotoxigenic Escherichia coli not belonging to the classical serotypes. Infection and Immunity 15, 549 555.

Hoekstra, D., Van der laan, J. W., De LeiJ, L. \& WitholT, B. (1976). Release of outer membrane fragments from normally growing Escherichia coli. Biochimica et biophysica acta 455, 889-899.

HohmanN, A. \& Wilson, M. R. (1975). Adherence of enteropathogenic Escherichia coli to intestinal epithelium in vivo. Infection and Immunity 12, 866-880.

Holmgren, J., LönNROTH, I., MANSSON, J. E. \& SVENNERHOLM, L. (1975). Interaction of cholera toxin and membrane $\mathrm{G}_{\mathrm{M} 1}$ ganglioside of small intestine. Proceedings of the National Academy of Sciences of the United States of America 72, 2520 2524.

ISAACSON, R. E. (1977). K99 surface antigen of Escherichia coli: purification and partial characterization. Infection and Immunity 15, 272-279.

JONES, G. W. \& RUTTER, J. M. (1972). Role of the K88 antigen in the pathogenesis of neonatal diarrhoea caused by Escherichia coli in piglets. Infection and Immunity 6, 918-927.

Kessler, M., ACuto, O., Storelli, C., Murer, H., MülleR, M. \& SemenzA, G. (1978). A modified procedure for the rapid preparation of efficiently transporting vesicles from small intestinal brush border membranes. Biochimica et biophysica acta 508 , 136-154.

KING, G. J. \& Swanson, J. (1978). Studies on Gonococcus infection. XV. Identification of surface proteins of Neisseria gonorrhoeae correlated with leukocyte association. Infection and Immunity 21, 575-584.

LAEMMLI, U. K. (1970). Cleavage of structural proteins during the assembly of the head of bacteriophage T4. Nature, London 227, 680-685.

Maestracci, D., Preiser, H., Hedges, T., Schmitz, J. \& Crane, R. K. (1975). Enzymes of the human intestinal brush border membrane; identification after gel electrophoretic separation. Biochimica et biophysica acta 382, 147-156.

MidDeldoRP, J. M. \& WitholT, B. (1981). K88mediated binding of Escherichia coli outer membrane fragments to porcine intestinal epithelial cell brush borders. Infection and Immunity 31, 42-51.

MooI, F. R. \& DE GRAAFF, F. K. (1979). Isolation and characterization of $\mathrm{K} 88$ antigens. FEMS Microbiology Letters 5, 17-21.

Moon, H. W., Nagy, B. \& Isaacson, R. E. (1977). Intestinal colonization and adhesion by enterotoxigenic Escherichia coli: ultrastructural observations on adherence to ileal epithelium of the pig. Journal of Infectious Diseases 136, S124-129.

MoOSeKer, M. S. (1976). Brush border motility: microvilla contraction in triton treated brush borders isolated from intestinal epithelium. Journal of Cellular Biology 71, 417-433.

Mug-Opstelten, D. \& Witholt, B. (1978). Preferential release of new outer membrane fragments by exponentially growing Escherichia coli. Biochimica et biophysica acta 508, 287-295.

NAGY, B., MoON, H. W. \& IsaAcson, R. E. (1976). Colonization of porcine small intestine by Escherichia coli: ileal colonization and adhesion by pig enteropathogens that lack K88 antigen and by some acapsular mutants. Infection and Immunity 13, 12141220.

NaGy, B., Moon, H. W. \& Isaacson, R. E. (1977). Colonization of porcine intestine by enterotoxigenic Escherichia coli: selection of piliated forms in vivo, adhesion of piliated forms to epithelial cells in vitro, and incidence of a pilus antigen among porcine enteropathogenic $E$. coli. Infection and Immunity 16, 344-352.

Orskov, I., Orskov, F., JANN, B. \& JANN, K. (1977). Serology, chemistry and genetics of $O$ and $K$ antigens of Escherichia coli. Bacteriological Reviews 41, 667-710.

Richards, K. L. \& Douglas, S. D. (1978). Pathophysiological effects of Vibrio cholerae and enterotoxigenic Escherichia coli and their enterotoxins on eucaryotic cells. Microbiological Reviews 42, 592613.

Sellwood, R., Gibbons, R. A., Jones, G. W. \& RUTTER, J. M. (1975). Adhesion of enteropathogenic Escherichia coli to pig intestinal brush borders: the existence of two phenotypes. Journal of Medical Microbiology 8, 405-411.

Shipley, P. L., Gyles, C. L. \& Falkow, S. (1978). Characterization of plasmids that encode for the $\mathrm{K} 88$ colonization antigen. Infection and Immunity $\mathbf{2 0}$, 559-566.

STIRM, S., Orskov, F., Orskov, I. \& MaNSA, B. (1967). Episome-carried surface antigen K88 of Escherichia coli. II. Isolation and chemical analysis. Journal of Bacteriology 93, 731-739.

Svanborg Eden, C., Eriksson, B. \& Hanson, L. A. (1977). Adhesion of Escherichia coli to human uroepithelial cells in vitro. Infection and Immunity 18, 767-774.

VoGEl, H. J. \& BoNNER, D. M. (1956). Acetylornithinase of Escherichia coli: partial purification and some properties. Journal of Biological Chemistry 218, 97-106. 
Webster, H. L. \& Harrison, D. D. (1969). Enzymic activities during the transformation of crypt to. columnar intestinal cells. Experimental Cell Research 56, 245-253.

Wensink, J., Gankema, H., Jansen, W. H., Guinée, P. A. M. \& WITHOLT, B. (1978). Isolation of the membranes of an enterotoxigenic strain of Escherichia coli and distribution of enterotoxin activity in different subcellular fractions. Biochimica et biophysica acta 514, 128-136.

WensinK, J. \& WitholT, B. (1981). Outer membrane vesicles released by normally growing Escherichia coli contain very little lipoprotein. European Journal of Biochemistry 116, 331-335.

WILSON, M. R. \& HohmanN, A. W. (1974). Immunity to Escherichia coli in pigs: adhesion of enteropathogenic Escherichia coli to isolated intestinal epithelial cells. Infection and Immunity 19, 776-782. Witholt, B., Boekhout, M., Brock, M., Kingma, J., VAN HeErikhuizen, H. \& De LeIJ, L. (1976). An efficient and reproducible procedure for the formation of spheroplasts from variously grown Escherichia coli. Analytical Biochemistry 74, 160-170. 